\title{
Investment Attitude in Gold- An Investors Perspective
}

\author{
${ }^{1}$ Vipin Benny, ${ }^{2}$ Biju John. M., \\ ${ }^{I}$ Assistant Professor, Department of Commerce \& Management Studies, \& Management Studies St. Thomas \\ College Jubilee Block, Thrissur - 680001 Kerala \\ ${ }^{2}$ Associate Professor, Department of Commerce \& Management Studies, \& Management Studies St. Thomas \\ College Thrissur - 680001 Kerala
}

\begin{abstract}
Gold occupies a pivotal role in the social and economic life of poor and rich alike. In India, besides the economic and strong social considerations, individuals are highly sentimental about the gold in their possession, as the gold ornaments are passed on from one generation to another. Acquisition of gold is considered auspicious and necessary for making family ornaments to get a sense of wellbeing in our country. Gold is increasingly considered as an investment that appreciates over years and provides a hedge against inflation and also medium that can be pledged easily during difficult times for securing financial accommodation.
\end{abstract}

Key words: GVA (Gross value added), GDP (Gross domestic product), (ETFs) Exchange Trades Funds.

\section{Introduction}

India's domestic production of gold is very limited and rising demand has to be sourced from outside the country. Moreover, Gold as a commodity on its own does not add much to the productive capacity of the economy. When one buys gold, it either is stored in lockers or gets converted into jewelry. In both the cases, money spent on purchasing gold gets blocked since gold is not a productive asset. The Indian government and the central banking authority of India, the Reserve Bank of India (RBI) are not too happy about the fact that Indians can't get over their fascination for physical gold. The Indian government on its part has tried very hard to make physical gold less attractive by raising duties on gold as well as forbidding banks from lending money to its customers for the purchase of gold. Even non bank financial companies (NBFCs) who till last year were gung ho about lending money against gold jewelry, have been snubbed. NBFCs can now only lend up to $60 \%$ of the value of gold that is being offered by the borrower as against $80 \%$ to $85 \%$ permitted earlier. The government's push behind making the shine of yellow metal less attractive to Indians is understandable

\section{Statement of the problem}

In much of Asia, the Middle East, and the Indian subcontinent, gold is the best possible protection against upheaval, both political and economic. For men and women throughout the developing world, gold is still one of the most liquid and widely accepted forms of exchange, quite simply the most efficient store of value they possess. The present study aims to put on some knowledge about how investors age, education and income level impact on gold investment.

\section{Objective of the study}

$>$ To measure the gold investment attitude of individual investor.

$>$ To know the impact of age, education and income factors in the investment attitude of investor.

\section{Research methodology}

The area of survey for this study was confined to Thrissur district in Kerala. Thrissur is the cultural capital of Kerala. Here is located the 70\% gold business of Kerala. The goldsmiths and the related industries are located near the city and premises villages. Professionals, businessmen and people with different income group live here providing necessary scope to undertake this survey. This study used both primary and secondary data. Totally 300 samples were collected by using simple random sampling method. The primary data collected from the respondents through questionnaire. The secondary data collected with help of various manuals, internet, journal, books etc

\section{Gold investment scenario-Scope of analysis and approach}

The analysis of the supply of gold focuses on mine production and the recycling of gold whilst the demand side analysis focuses on gold fabrication (primarily for jeweler and technology) and certain forms of investment (principally bar and coin). The economic analysis concentrates on the direct economic impacts: none 
of the indirect, induced or wider economic impacts that might arise is considered systematically. The key metrics are GVA - which measures the economic contribution of those entities engaged in the gold value chain and reflects their contribution to the economies in which they operate - and employment. GVA is used because it measures the value of an activity in a way which lends itself to direct comparison with Gross Domestic Product, which is used worldwide to measure economies' economic output. The fiscal analysis focuses on the revenues derived by governments from those taxes and other fiscal measures which are peculiar to the extraction and use of gold rather than those which apply to all or most businesses regardless of their sector (e.g. corporation tax). This is largely because of the practical difficulties of assessing the scale of all these taxes on a consistent basis.

The supply of gold: Global gold supply reached 4,753 tonnes in 2013. Approximately two thirds of new gold supply each year comes from mining with the remaining one third coming from the recycling of gold.

\section{$>$ Mine production}

Global mine production was 2,938 tonnes in 2013. Mines in the top 15 gold producing countries extracted 2300 tonnes of gold in 2013, 78\% of the world total. The six largest producers, China, Australia, the United States, Russia, Peru and South Africa, extracted more than half of the gold mined globally. The gold mines in the world's top 15 producing countries are estimated to have generated US $\$ 80.4$ billion of direct GVA in 2013. This is equal to the entire national economic output of Ecuador or Azerbaijan or 33\% of the estimated GDP of Shanghai.

China is estimated to derive the largest economic contribution directly from gold mining at US\$13.6 billion in 2013, although this is only a small proportion of the total output of the world's second largest economy $(0.3 \%)$.The employment supported by gold mines is an alternative measure of economic contribution. Total direct employment in gold mining across the 15 largest gold mining countries is estimated to be 528,900 in 2013. These estimates understate significant employment in artisanal and small scale production outside the formal sector as well as the indirect and induced employment attributable to gold mining.

\section{$>$ Recycling of gold}

Recycling of gold is the other significant source of gold supply accounting for around $38 \%$ of global supply in 2013. The location of gold recycling activity is not tied to mine production and is more likely to be linked to gold consumption. Data limitations, including the lack of information on the countries in which recovered gold is subsequently refined, mean that the GVA of gold recycling cannot be estimated at the country level.

Demand for gold: The uses of gold are wide-ranging reflecting both the physical appearance and properties of gold and its advantages as a store of value. In 2013, investment demand (consisting of bar and coin and goldbacked Exchange Trades Funds (ETFs) accounted for 35\%, central bank gold purchases accounted for 12\%, jewelry accounted for $43 \%$ and use in technology/manufacturing accounted for around $10 \%$ of gold demand. The 13 largest gold consuming countries in 2013 accounted for $75 \%$ of gold used for fabrication and $81 \%$ of that used for (final) consumption, either in the form of jewelry or investment products such as small bars and coins. By far, the two largest consuming countries are India and China. The analysis of the economic impact of gold demand has focused on three segments of the market:

$>$ Bar and coin fabrication and consumption;

$>$ Jewelry fabrication and consumption; and

$>$ Technology/manufacturing (e.g. electronics, decorative uses and dentistry)

In each case, the focus is on providing estimates of the GVA attributable to gold during the fabrication process. In addition, the wholesale/retail GVA is also estimated for jewellery and bar and coin: in the case of manufacturing uses, the complexity of the relevant value chains allied to a lack of data on the consumption of those manufactured goods which use gold as an input, precludes analysis of the GVA of retail activity of these manufactured goods.

\section{$>$ Bar and coin}

Gold bar and coin is the most important form of investment by volume. Bar and coin demand has surged following the financial crisis and accounted for the largest proportion $(82 \%)$ of total investment demand in 2013. The direct GVA associated with bar and coin fabrication is estimated in two steps. First, the mark-up achieved by fabricators is applied to the value of the purchases of gold to estimate their turnover. Second, the GVA is then estimated by multiplying the estimated turnover by the share of turnover that is GVA. In total, the direct GVA associated with the fabrication of gold bars and coins is estimated to be US $\$ 13.3$ billion across the 
top 13 consuming countries, led by India, China and Vietnam. The direct GVA associated with the consumption of bar and coin is estimated in a similar way. First, the markup achieved by sellers of bar and coin over the underlying cost of the gold is estimated to derive turnover. Second, the share of this turnover that is GVA is then estimated. In total, the direct GVA associated with the consumption of gold bar and coin is estimated to be US $\$ 38.3$ billion across the top 13 consuming countries, led by India, China and Vietnam.

\section{$>$ Jewellery}

Jewellery accounts for the largest proportion of gold fabrication and consumption demand. India and China account for more than half of global gold jewellery fabrication and consumer demand.

Data from national governments do not typically provide the level of granularity required to assess the GVA of the fabrication of gold jewellery directly. Consequently, it is estimated by using the mark-up achieved by fabricators and retailers on purchases of gold to estimate the turnover linked to gold consumption in jewellery. Overall, the direct GVA attributable to gold jewellery fabrication and consumption across the top 13 gold consuming countries is estimated at US\$69.8 billion. Although China fabricates and consumes less gold than India, its total GVA exceeds that of India because it adds more value per ounce of gold.

\section{$>$ Technology}

Gold is used in a wide range of technological/manufacturing applications because of its electrical conductivity, malleability and resistance to corrosion. Applications include electronic goods and equipment, telecommunications devices and household appliances. Gold is also used in healthcare services and pharmaceutical products due to its "biocompatibility" and resistance to bacterial colonization. Global technology fabrication demand amounted to around 418 tonnes in 2013, with gold destined for the electronics industry accounting for the largest share. The United States is the largest consumer of gold for technology purposes followed by China and Germany.

\section{$>$ The gold value chain}

The analysis considers the supply of gold separately from the demand for gold. The supply side analysis focuses on mine production and gold recycling. The demand side analysis focuses on the use of gold in fabrication.

\section{Figure 1: The gold value chain}
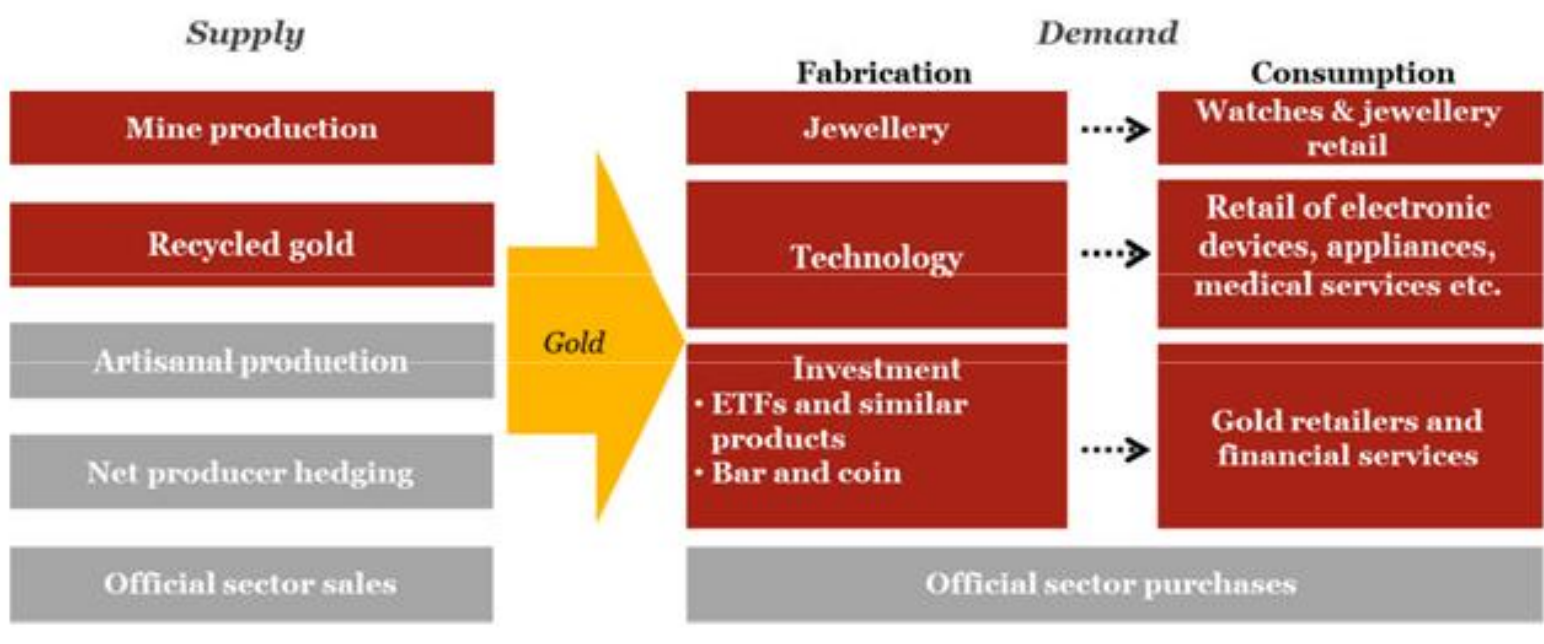

\section{Data analysis}

The three factors viz., age, education and income level which are influencing the investor while selecting investment in gold. $\mathrm{H} 1$ is the alternative hypothesis specify the relationship between the factors viz., age, education and income level in investing gold and $\mathrm{H} 0$ is the null hypothesis specifies there is no relationship between the factors age, education and income level in investing gold (Chi-square test). 


\section{Chi-square test}

Table 1: Gold investment attitude related with age of investors

\begin{tabular}{|c|c|c|c|c|}
\hline Age & $\begin{array}{l}\text { Investment in } \\
\text { commodity market }\end{array}$ & $\begin{array}{l}\text { Physical gold } \\
\text { purchased in the } \\
\text { form of ornaments }\end{array}$ & $\begin{array}{l}\text { Physical gold } \\
\text { purchased in the } \\
\text { form of Kilo bars }\end{array}$ & $\begin{array}{l}\text { Purchase through } \\
\text { bank }\end{array}$ \\
\hline $25-35$ & $12(16.5)$ & $38(32.4)$ & $16(18.6)$ & $24(22.5)$ \\
\hline $36-46$ & $24(20.35)$ & $34(39,96)$ & $22(22.94)$ & $31(27.75)$ \\
\hline Above 47 & $19(18.15)$ & $36(35.64)$ & $24(20.46)$ & $20(24.75)$ \\
\hline
\end{tabular}

\section{Source: Primary data}

\section{Hypothesis}

$\mathrm{H} 0=$ There is no relationship between investors age and attitudes towards gold investment. $\mathrm{H} 1=$ There is relationship between investors age and attitudes towards gold investment.

Degree of freedom $=($ Column -1$) X($ Row -1$)=(4-1) X(3-1)=3$ X 2=6, Critical value for Chi-square distribution degree of freedom (df) $12.592=($ at $5 \%$ level of significance), Calculated value $=6.189$, so calculated value is lower than the table value $(12.592>6.189)$.

Hence, the calculated value 6.189 is lower than the table value 12.592.So $\mathrm{H} 0$ is accepted which specifies there is no relationship between investor age and attitudes towards gold investment.

\section{Chi-square test}

Table 2: Gold investment attitude related with education of investors

\begin{tabular}{|l|l|l|l|l|}
\hline & $\begin{array}{l}\text { Investment in commodity } \\
\text { Earket }\end{array}$ & $\begin{array}{l}\text { Physical gold purchased } \\
\text { in the form of ornaments }\end{array}$ & $\begin{array}{l}\text { Physical gold } \\
\text { purchased in the } \\
\text { form of Kilo bars }\end{array}$ & Purchase through bank \\
\hline Under graduate & $10(10.78)$ & $25(14.54)$ & $6(12.57)$ & $8(11.11)$ \\
\hline Graduate & $26(24.86)$ & $28(33.52)$ & $31(29)$ & $28(25.61)$ \\
\hline Post graduate & $30(30.36)$ & $36(40.94)$ & $40(35.42)$ & $32(31.28)$ \\
\hline
\end{tabular}

Source: Primary data

\section{Hypothesis}

$\mathrm{HO}=$ There is no relationship between investors education and attitudes towards gold investment.

$\mathrm{H} 1$ = There is relationship between investors education and attitudes towards gold investment.

Degree of freedom $=($ Column -1$) X($ Row -1$)=(4-1) X(3-1)=3 \times 2=6$, Critical value for Chi-square distribution degree of freedom (df) $12.592=$ (at $5 \%$ level of significance), Calculated value $=14.427$, so calculated value is greater than the table value $(14.427>12.592)$.

Hence, the calculated value 14.427 is greater than the table value 12.592. So $\mathrm{H} 0$ is rejected which specifies there is relationship between investor education and attitudes gold investment.

\section{Chi-square test}

Table 3: Gold investment attitude related with income level of investor

\begin{tabular}{|l|l|l|l|l|}
\hline Income level & $\begin{array}{l}\text { Investment in commodity } \\
\text { market }\end{array}$ & $\begin{array}{l}\text { Physical gold purchased } \\
\text { in the form of ornaments }\end{array}$ & $\begin{array}{l}\text { Physical gold purchased } \\
\text { in the form of Kilo bars }\end{array}$ & \begin{tabular}{l} 
Purchase through bank \\
\hline Less than 15000
\end{tabular} $8(10.70)$ \\
\hline $15001-30000$ & $26(27.01)$ & $23(12.76)$ & $5(11.44)$ & $8(9.09)$ \\
\hline Above 30000 & $39(35.28)$ & $28(32.19)$ & $32(28.86)$ & $25(22.94)$ \\
\hline
\end{tabular}

\section{Source: Primary data}

\section{Hypothesis}

$\mathrm{H} 0=$ There is no relationship between investors income level and attitudes towards gold investment. $\mathrm{H} 1=$ There is relationship between investors income level and attitudes towards gold investment.

Degree of freedom $=($ Column -1$) X($ Row -1$)=(4-1) X(3-1)=3 \times 2=6$, Critical value for Chi-square distribution degree of freedom (df) $12.592=$ (at $5 \%$ level of significance), Calculated value $=15.35$, so calculated value is greater than the table value $(15.35>12.592)$. 
Hence, the calculated value 15.35 is greater than the table value 12.592.So H0 is rejected which specifies there is relationship between investor's income level and attitudes towards gold investment.

\section{Conclusion}

Investment in gold consisting of bar and coin and gold-backed exchange traded funds (ETFs) accounted for $35 \%$ of global gold demand, central bank gold purchases accounted for $12 \%$, jewellery accounted for $43 \%$ and use in technology/manufacturing accounted for around $10 \%$ of gold demand. From the above study can be concluding that investors education and income levels are crucial elements in making investment in gold.

\section{Reference}

[1]. Preethi Singh (2006), Investment Management, Himalaya Publishing House, Mumbai.

[2]. Gupta .S.P. (2008), Statistical Methods, Sultan Chand \& Sons Company Ltd., New Delhi.

[3]. Kothari.C.R.(2009), Research Methodology Methods and Techniques, Wishwaprakashan, New Delhi.

[4]. Schiffman, G Leon., Kanuk, Lazar Leslie., Consumer Behavior, 9th edition., New Delhi: Pearson Education., 2009

[5]. Malhotra, K Naresh., Marketing Research, $5^{\text {th }}$ edition.,New Delhi: Pearson Education., 2009.

\section{Websites}

http://www.google.com

http://www.pwc.co.uk 